\title{
Sodium Channel mRNAs at the Neuromuscular Junction: Distinct Patterns of Accumulation and Effects of Muscle Activity
}

\author{
Suad S. Awad, ${ }^{1}$ Robert N. Lightowlers, ${ }^{1}$ Carol Young,, ${ }^{1}$ Zofia M. A. Chrzanowska-Lightowlers, ${ }^{1}$ Terje Lømo, ${ }^{2}$ \\ and Clarke R. Slater ${ }^{1}$ \\ ${ }^{1}$ Department of Neuroscience, University of Newcastle upon Tyne, NE2 4HH, Newcastle upon Tyne, United Kingdom, \\ and ${ }^{2}$ Department of Physiology, University of Oslo, 0317 Oslo, Norway
}

\begin{abstract}
Voltage-gated sodium channels (VGSCs) are highly concentrated at the neuromuscular junction (NMJ) in mammalian skeletal muscle. Here we test the hypothesis that local upregulation of mRNA contributes to this accumulation. We designed radiolabeled antisense RNA probes, specific for the "adult" $\mathrm{Na}_{\mathrm{V}} 1.4$ and "fetal" $\mathrm{Na}_{\mathrm{v}} 1.5$ isoforms of VGSC in mammalian skeletal muscle, and used them in in situ hybridization studies of rat soleus muscles. $\mathrm{Na}_{\mathrm{v}} 1.4 \mathrm{mRNA}$ is present throughout normal adult muscles but is highly concentrated at the NMJ, in which the amount per myonucleus is more than eightfold greater than away from the NMJ. $\mathrm{Na}_{\mathrm{v}} 1.5$ mRNA is undetectable in innervated muscles but is dramatically upregulated by denervation.
\end{abstract}

Voltage-gated sodium channels (VGSCs) play a central role in action potential generation and propagation in mammalian nerve and muscle. In neurons, they are concentrated at sites in which action potentials are initiated: the axon hillock and the initial segments (Wollner and Catterall, 1986). In skeletal muscle, VGSCs are concentrated at neuromuscular junctions (NMJs), in the depths of the postsynaptic folds, alternating with acetylcholine receptor (AChR)-rich domains at the crests of the folds (Flucher and Daniels, 1989; Boudier et al., 1992; Lupa et al., 1993; Wood and Slater, 1998). This juxtaposition of ligand- and voltage-gated ion channels at the NMJ increases the reliability of neuromuscular transmission (Martin, 1994; Wood and Slater, 1997, 2001). VGSCs are also present in lower concentrations in extrajunctional $(\mathrm{XJ})$ regions of muscle fibers in which they mediate action potential propagation (Lupa et al., 1993; Wood and Slater, 1998).

Little is known about how the distribution of VGSCs in muscle fibers is controlled. Previous studies of a number of other proteins that are concentrated in the postsynaptic region [e.g., AChRs, acetylcholinesterase (AChE), rapsyn, utrophin, and neural cell adhesion molecule (N-CAM)] have revealed that the mRNAs encoding them are also concentrated near the NMJ (for review, see Hall and Sanes, 1993; Burden, 1998; Sanes and Lichtman, 1999). However, in contrast to most of these other proteins, VGSCs have a well defined role away from the NMJ, as well as in the junctional $(\mathrm{J})$ region. This raises the possibility that the

\footnotetext{
Received April 24, 2001; revised June 20, 2001; accepted Aug. 13, 2001.

This work was supported by grants from the European Union Biotechnology Program (Contract BIO4-CT96.0216) and The Wellcome Trust (Z.M.A.C.-L. is a Wellcome Trust Career Development Fellow).

Correspondence should be addressed to Dr. S. S. Awad, Department of Neuroscience, School of Neurosciences and Psychiatry, The Medical School, University of Newcastle upon Tyne, Newcastle upon Tyne, NE2 4HH, UK. E-mail: s.s.awad@ncl.ac.uk.

Copyright (C) 2001 Society for Neuroscience $\quad 0270-6474 / 01 / 218456-08 \$ 15.00 / 0$
}

In muscles denervated for 1 week, both $\mathrm{Na}_{\mathrm{v}} 1.4$ and $\mathrm{Na}_{\mathrm{v}} 1.5$ mRNAs are present throughout the muscle, and both are concentrated at the NMJ. No $\mathrm{Na}_{\mathrm{V}} 1.5 \mathrm{mRNA}$ was detectable in denervated muscles stimulated electrically for 1 week in vivo. Neither denervation nor stimulation had any significant effect on the level or distribution of $\mathrm{Na}_{v} 1.4$ mRNA. We conclude that factors, probably derived from the nerve, lead to the increased concentration of VGSC mRNAs at the NMJ. In addition, the expression of $\mathrm{Na}_{\mathrm{v}} 1.5$ mRNA is downregulated by muscle activity, both at the NMJ and away from it.

Key words: neuromuscular junction; sodium channels; denervation; electrical activity; rat; in situ hybridization

mechanisms that determine the distribution of VGSCs may differ from those for other postsynaptic proteins. Previous studies have described the presence of mRNA encoding VGSCs in whole muscle fibers (Kallen et al., 1990; Yang et al., 1991; Lupa et al., 1993, 1995), but the question of whether there is an additional increase in mRNA at the NMJ, and if so how it is regulated, has not been addressed.

In this study, we used in situ hybridization (ISH) to determine whether mRNA species encoding VGSCs are concentrated at NMJs in adult rat muscle. Two isoforms of VGSCs, $\mathrm{Na}_{\mathrm{V}} 1.4$ and $\mathrm{Na}_{\mathrm{V}} 1.5$, encoded by two separate genes, are expressed in mammalian skeletal muscle (Trimmer et al., 1989; Kallen et al., 1990). The $\mathrm{Na}_{\mathrm{V}} 1.4$ isoform, which is relatively sensitive to tetrodotoxin, predominates in the adult. It is present throughout the muscle fiber but is concentrated at the NMJ and perijunctional regions (Flucher and Daniels, 1989; Lupa et al., 1993; Wood and Slater, 1998). The $\mathrm{Na}_{\mathrm{V}} 1.5$ isoform, which is relatively resistant to tetrodotoxin, predominates in immature muscle and is reexpressed in denervated and paralyzed muscle (Harris and Thesleff, 1971; Kallen et al., 1990; Lupa et al., 1995; Pasino et al., 1996). It seems likely that muscle activity is an important determinant of the global expression of the $\mathrm{Na}_{\mathrm{V}} 1.5$ gene in muscle fibers, although this has not been demonstrated directly. We therefore studied the effect of denervation, and of subsequent direct muscle stimulation, on the distribution and abundance of both species of $\mathrm{Na}_{\mathrm{V}} 1$ mRNA.

\section{MATERIALS AND METHODS}

Muscle denervation and stimulation. Experiments were performed on soleus muscles from adult female Wistar rats weighing 200-300 gm. Muscles were denervated under halothane anesthesia $(2.5 \%)$ by unilateral removal of $\sim 5 \mathrm{~mm}$ of the sciatic nerve at midthigh level. Soleus muscles were removed at different times after denervation. All animals were treated in accordance with local animal care regulations in the United Kingdom. 

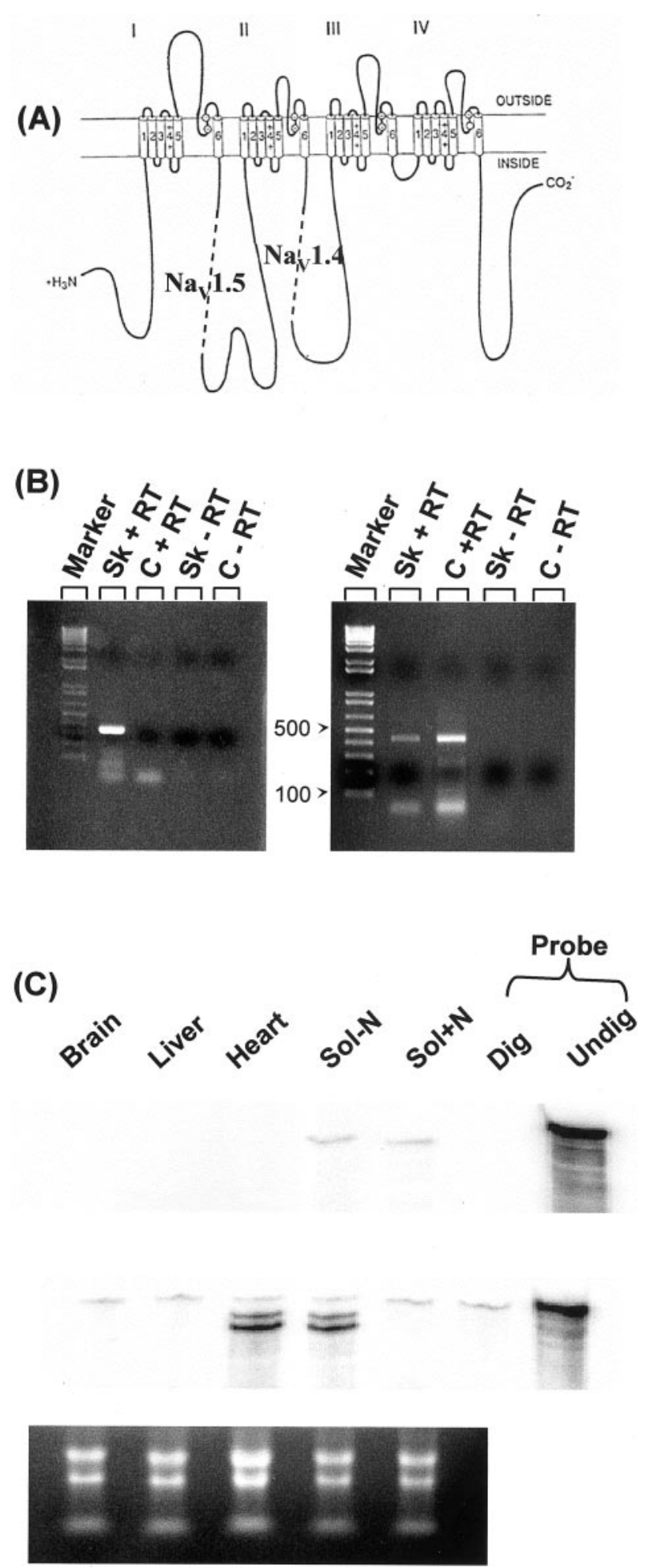

Figure 1. Generation of isoform-specific probes for VGSCs. A, Primary structure of $\alpha$-subunit of VGSC (adapted from Catterall, 1992). The location of sequences used to make probes for $\mathrm{Na}_{\mathrm{V}} 1.4$ and $\mathrm{Na}_{\mathrm{V}} 1.5$ isoforms are indicated by broken lines in cytoplasmic domains I and II. B, Agarose gel electrophoresis (1\%) of RT-PCR products from skeletal ( $S k$ ) and cardiac $(C)$ muscles using isoform-specific oligonucleotide primers. The $\mathrm{Na}_{\mathrm{V}} 1.4$-specific primer set (Materials and Methods) amplified the correct 349 bp product from skeletal but not from cardiac cDNA (left panel). The $\mathrm{Na}_{\mathrm{V}} 1.5$-specific fragment (410 bp) is amplified from both skeletal cardiac muscle cDNAs (right panel). No products are detected in the absence of reverse transcriptase using either primer set ( $-R T$ lanes).
Electrical stimulation was performed in Norway on muscles that had been denervated for $5 \mathrm{~d}$. Electrodes were implanted on each side of the soleus muscle as described previously (Windisch et al., 1998). The muscle was stimulated for 1 week with trains of 60 pulses at $100 \mathrm{~Hz}$ every $60 \mathrm{sec}$. Muscles were removed using RNase-free instruments and reagents, and the midbelly portion was frozen in isopentane cooled to $-150^{\circ} \mathrm{C}$ with liquid nitrogen for ISH experiments (see below). Soleus muscles from unoperated rats of the same age were used as controls. The experiments were conducted in conformity with regulations for experiments on live animals in Norway and overseen by the veterinarian responsible for the animal house.

Synthetic oligonucleotide primers. The $\mathrm{Na}_{\mathrm{V}} 1.4$-specific probe was designed from the published cDNA sequence of the $\alpha$-subunit of the rat $\mathrm{Na}_{\mathrm{V}} 1.4$ sodium channel (Trimmer et al., 1989; GenBank accession number M26643). Specific oligonucleotide primers were designed from an area of low homology with $\mathrm{Na}_{\mathrm{V}} 1.5$ in the cytoplasmic loop between the transmembrane domains DII and DIII (Fig. $1 A$ ): sense primer, 5' AATACTCAGCCTCGGTGAGC 3' [nucleotide (nt) 2993-3012]; antisense primer, 5' CTTGTAGTCAGCTGTGCTGC 3' (nt 3341-3322).

The $\mathrm{Na}_{\mathrm{V}} 1.5$-specific probe is contained in the cytoplasmic loop between DI and DII and includes an insertion in this region (Fig. 1 $\mathrm{A}$ ). Specific oligonucleotide primers were designed from the published rat cardiac $\alpha$-subunit cDNA sequence [sense primer, 5' AGCTCTCTGGAGATGTCTCC 3' (nt 1575-1594); antisense primer, 5' ACGGTGCTGTTCCTTTTGCC 3' (nt 1984-1965)] and were used in reverse transcription (RT)-PCR to amplify a 410 bp fragment (Rogart et al., 1989; GenBank accession number M27902). All synthetic oligonucleotide primers were obtained from MWG Biotech (Milton Keynes, UK).

$R N A$ isolation, first-strand $c D N A$ synthesis, and PCR. Total RNA was isolated from liver, brain, soleus, and cardiac muscles using TRIZOL reagent and used for cDNA synthesis with oligo- $\mathrm{dT}_{12-18}$ primer following the recommendations of the manufacturer (Life Technologies, Paisley, UK). Negative controls were performed in the absence of reverse transcription.

Ten percent of the first-strand cDNA from soleus and cardiac muscle was used in a PCR reaction with 50 pmol of each of the isoform-specific oligonucleotide primers. Amplification conditions for the $\mathrm{Na}_{\mathrm{V}} 1.4$-specific primer set were as follows: first step of denaturation at $94^{\circ} \mathrm{C}$ for $3 \mathrm{~min}$, followed by 35 cycles of $94^{\circ} \mathrm{C}$ for $1 \mathrm{~min}, 59^{\circ} \mathrm{C}$ for $1 \mathrm{~min}$, and $72^{\circ} \mathrm{C}$ for 1 min, followed by extension at $72^{\circ} \mathrm{C}$ for 3 min. A product of $349 \mathrm{bp}$ was generated from skeletal muscle, but no product was amplified from cardiac cDNA (Fig. 1B).

Amplification conditions with the $\mathrm{Na}_{\mathrm{V}} 1.5$-specific primer set were as for $\mathrm{Na}_{\mathrm{V}} 1.4$, except that primer annealing was performed at $54^{\circ} \mathrm{C}$. A 410 bp product was generated from both skeletal and cardiac cDNA. A low level of tetrodotoxin-resistant sodium current has been reported in adult skeletal muscle (Lupa et al., 1993), and this may explain PCR amplification of the $\mathrm{Na}_{\mathrm{V}} 1.5$-specific fragment from skeletal muscle cDNA in our experiments.

PCR-generated fragments were subcloned into pGEM-T easy vector (Promega, Southampton, UK) following the recommendations of the manufacturer, and the identity of the cloned fragments was verified by DNA sequence analysis (Molecular Biology Service Unit, University of Newcastle upon Tyne).

RNase protection assays. Vector constructs containing $\mathrm{Na}_{\mathrm{V}} 1.4-$ or $\mathrm{Na}_{\mathrm{V}} 1.5$-specific fragments were linearized (Spe1 or Apa1, respectively)

$\leftarrow$

The first lane in each panel contains a molecular size marker (Life Technologies). $C$, RPA using isoform-specific antisense RNA probes. The $\mathrm{Na}_{\mathrm{V}} 1.4$-specific (top panel) and $\mathrm{Na}_{\mathrm{V}} 1.5$-specific (bottom panel) probes were labeled with $\left[\alpha{ }^{32} \mathrm{P}\right] \mathrm{UTP}$ and hybridized with $10 \mu \mathrm{g}$ of total RNA from brain, liver, heart, and innervated $(\mathrm{Sol}+\mathrm{N})$ and denervated $(\mathrm{Sol}-\mathrm{N})$ soleus muscles (see Materials and Methods). The $\mathrm{Na}_{\mathrm{V}} 1.4$ probe protected a fragment of expected size from both innervated and denervated soleus but none from brain, liver, or cardiac RNA. Hybridization with the $\mathrm{Na}_{\mathrm{V}} 1.5$-specific probe resulted in protection of two fragments from cardiac and denervated soleus RNA, one smaller than the expected size. No protected fragments are detected from liver, brain, or innervated soleus muscle RNA (middle panel). Digested (Dig) and undigested (Undig) probe controls were run in adjacent lanes in each gel. The bottom panel shows a denaturing agarose gel electrophoresis (1\%) of an aliquot total cytosolic RNA used for RPA, demonstrating intact $28 \mathrm{~S}$ and $18 \mathrm{~S}$ ribosomal RNA bands and 5 S RNA at the bottom of the ethidium bromide-stained gel. 
and used as in vitro transcription (IVT) templates in the presence of $\left[\alpha-{ }^{32} \mathrm{P}\right] \mathrm{UTP}(800 \mathrm{Ci} / \mathrm{mmol}$; Amersham Pharmacia Biotech, Bucks, UK) to synthesize the antisense $\mathrm{Na}_{\mathrm{V}} 1.4$ (T7 RNA polymerase-driven) or $\mathrm{Na}_{\mathrm{V}} 1.5$ (SP6 RNA polymerase-driven; Roche Diagnostics, Lewes, UK) probes. IVT was performed. Labeled probe $\left(6 \times 10^{4} \mathrm{cpm}\right)$ was hybridized for $48 \mathrm{hr}$ with $10 \mu \mathrm{g}$ of total cytosolic RNA at $42^{\circ} \mathrm{C}$. Samples were then digested for 30 min with RNase A/T1 mix at $37^{\circ} \mathrm{C}$ (RPAIII kit; Ambion, Austin, TX) and electrophoresed on $5 \%$ denaturing polyacrylamide urea gels in $1 \times$ Tris-borate-EDTA buffer, together with the digested and undigested probe-alone controls. These controls indicate the efficiency of digestion, because the $\mathrm{Na}_{\mathrm{V}} 1.4$ - and $\mathrm{Na}_{\mathrm{V}} 1.5$-specific probes contained noncomplementary sequence of 64 and 129 nucleotides derived from polylinker sequences, respectively. The protected RNA fragments were visualized using a PhosphorImager and Image Quant software (Molecular Dynamics, Kent, UK). The $\mathrm{Na}_{\mathrm{V}} 1.4$-specific probe protected the correct size fragment from innervated and denervated adult skeletal muscle but not from heart, liver, or brain RNA (Fig. 1C). The $\mathrm{Na}_{\mathrm{V}} 1.5$-specific probe protected the correct size RNA and a smaller fragment from cardiac and denervated soleus muscle (Fig. 1C). No detectable products were identified from innervated soleus, liver, or brain RNA.

In situ hybridization. ISH was performed on 6 - $\mu$ m-thick frozen sections of adult rat soleus muscles as described previously (Vater et al., 1998; Young et al., 1998).

pGEM-T easy plasmids were linearized with $N c o 1$ and Spe1 $\left(\mathrm{Na}_{\mathrm{V}} 1.4\right)$ or Pst 1 and Apa $1\left(\mathrm{Na}_{\mathrm{V}} 1.5\right)$ restriction enzymes and used as templates for phage T7 and SP6-driven IVT to produce either sense- or antisensespecific probes, depending on the orientation of the insert. Transcripts were double-labeled with ${ }^{35} \mathrm{~S}-\mathrm{CTP}$ and ${ }^{35} \mathrm{~S}-\mathrm{UTP}(>1000 \mathrm{Ci} / \mathrm{mmol}$; Amersham Pharmacia Biotech). Sections were hybridized overnight with $10^{4}-10^{5} \mathrm{cpm} / \mu \mathrm{l}{ }^{35} \mathrm{~S}$-labeled probes in $40 \mu \mathrm{l}$ of hybridization buffer and washed as described previously (Young et al., 1998). NMJs were identified in the same fiber cross sections by the reddish-brown AChE reaction product (Young et al., 1998).

Autoradiography and analysis. Hybridized sections were air-dried, dipped in Kodak NTB2 emulsion (Anachem Scotlab, Luton, UK), exposed at $4^{\circ} \mathrm{C}$ for $7-10 \mathrm{~d}$, developed for $3 \mathrm{~min}$ at $17^{\circ} \mathrm{C}$ in Kodak Dektol developer, and counterstained with $0.25 \%$ toluidine blue in $1 \%$ borax.

Labeled sections were viewed with a Leica (Nussloch, Germany) DMRA microscope, and images were recorded, using both bright- and dark-field optics, with a cooled CCD camera with 12 bit intensity resolution (SPOT 2; Diagnostic Instruments, Sterling Heights, MI). The distribution and intensity of labeling were determined from dark-field images, substantially as described by Vater et al. (1998), using NIH Image software. The spatial distribution of labeling was determined from the mean signal intensity, expressed as gray levels per second exposure time per square micrometer $\left(\mathrm{gl} / \mathrm{sec} / \mu \mathrm{m}^{2}\right)$, in concentric annuli centered on the cluster being analyzed. At most clusters, both at the NMJ and in $\mathrm{XJ}$ regions, the intensity of labeling declined to $30 \%$ of maximum at $\sim 12$ $\mu \mathrm{m}$ from the center of the grain cluster, as reported previously for utrophin mRNA (Vater et al., 1998). For subsequent comparisons of the intensity of labeling at different grain clusters, we used the total signal intensity within a circle of $12 \mu \mathrm{m}$ radius, centered on the cluster.

The signal intensity of grain clusters at NMJs depended on the concentration of the radioactive probe used in the hybridization reactions. At $20 \times 10^{3} \mathrm{cpm} / \mu \mathrm{l}$, the labeling intensity with the $\mathrm{Na}_{\mathrm{V}} 1.4$ probe was well above background but still only approximately two-thirds of that with $100 \times 10^{3} \mathrm{cpm} / \mu \mathrm{l}$ (data not shown). Thus, at the lower concentration, the emulsion and detection system were not saturated. A concentration of $20 \times 10^{3} \mathrm{cpm} / \mu \mathrm{l}$ was therefore used in all subsequent experiments with the $\mathrm{Na}_{\mathrm{V}} 1.4$ probe. Similarly, optimum labeling with the $\mathrm{Na}_{\mathrm{V}} 1.5$ probe was obtained at $30 \times 10^{3} \mathrm{cpm} / \mu \mathrm{l}$, and this concentration was used in all experiments described.

Immunohistochemical staining and nuclear counting. We counted nuclei in cross sections of muscle fibers, using a method similar to that described previously by Zhang and McLennan (1994) and Vater et al. (1998), that allowed us to distinguish between true myonuclei (within labeled sarcolemma) and the nuclei of myosatellite cells, which are particularly abundant near the NMJ (Kelly and Zacks 1969).

Cryostat sections of adult soleus muscle were thaw mounted on chrome-alum gelatin-coated slides and labeled with a cocktail of a monoclonal antibody that recognizes the C-terminal domain of dystrophin, Dy8/6C5 (1:100 dilution; kind gift from Dr. Louise Anderson, University of Newcastle upon Tyne), and a monoclonal antibody that recognizes all forms of syntrophin $(1351 ; 1: 1000$; a kind gift from Prof.
Stanley C. Froehner, University of Washington, Seattle, WA). Antibodies were diluted in PBS containing 3\% serum albumin and $0.1 \mathrm{M}$ lysine. Antibody binding was visualized using horseradish peroxidaseconjugated rabbit anti-mouse Ig (P0260; Dako, High Wycombe, UK) and $3,3^{\prime}$ diaminobenzidine. Counterstaining with hematoxylin was used to visualize nuclei.

To analyze the distribution of nuclei, we used a crossed eyepiece graticule, centered on the muscle fiber section to be studied, dividing it into four quadrants numbered 1-4. Quadrant 1 included the NMJ if present. Myonuclei clearly inside the labeled surface of the muscle fiber were counted in each quadrant, in both sections containing NMJs and sections at least $100 \mu \mathrm{m}$ away from the NMJ in the same cross section (XJ). Nuclei that appeared to straddle the muscle fiber boundary, defined by immunolabeling, were not counted. These represented fewer than $5 \%$ of the true myonuclei counted.

Statistics. Data are expressed as mean \pm SEM. When appropriate, data were analyzed using either a two-way ANOVA (with Bonferroni correction) for multiple comparisons (Instat, version 1.11; Graph Pad, San Diego, CA) or Student's $t$ test (two-tailed) for paired comparisons.

\section{RESULTS}

\section{$\mathrm{Na}_{\mathrm{v}} 1.4$ mRNA of VGSCs is concentrated at the NMJ}

Probes specific for $\mathrm{Na}_{\mathrm{V}} 1.4$ and $\mathrm{Na}_{\mathrm{V}} 1.5$ were designed from the cytoplasmic loops of the $\alpha$-subunit between transmembrane domains DII-DIII and DI-DII, respectively (Fig. $1 A$ ). RNase protection assays (RPA) (Fig. 1C) confirmed that the two probes were isoform specific. These probes were then used to analyze the spatiotemporal distribution of mRNA encoding the two $\mathrm{Na}_{\mathrm{V}} 1$ isoforms.

After hybridization of sections of adult muscle with the ${ }^{35} \mathrm{~S}$ labeled $\mathrm{Na}_{\mathrm{V}} 1.4$ probe, dense accumulations of silver grains were present at $>80 \%$ (39 of 47 ) of NMJs examined [identified by AChE reaction product (Fig. $2 A$, arrow)]. Labeling intensity in a $12 \mu \mathrm{m}$ radius test circle centered on at the NMJ (see Materials and Methods) was nearly 20 times greater than the average intensity of labeling in XJ regions $(99.65 \pm 3.93$ vs $5.14 \pm 0.18$ $\mathrm{gl} / \mathrm{sec} / \mu \mathrm{m}^{2} ; 49 \mathrm{~J}$ clusters and $43 \mathrm{XJ}$ fiber cross sections were examined). There is generally more label near the surface than elsewhere in the muscle fiber.

After ISH, less dense accumulations were present in $\sim 30 \%$ of fiber cross sections (46 of 142) through XJ regions (Fig. $2 A$, arrowheads), and these were often clearly associated with myonuclei. Labeling intensity within a circle of $12 \mu \mathrm{m}$ radius centered on these XJ clusters was $\sim 30 \%$ of that at J clusters $(27.9 \pm 0.99$ $\mathrm{gl} / \mathrm{sec} / \mu \mathrm{m}^{2}$; $46 \mathrm{XJ}$ clusters were analyzed).

No hybridization above background was seen with the $\mathrm{Na}_{\mathrm{V}} 1.5$ probe (Fig. $2 C$ ). This lack of cross hybridization provides additional evidence of the specificity of our probes, as does the absence of detectable labeling in control experiments with sense probes (Fig. $2 B, D$ ) or with no probe controls (data not shown). These results were reproducible in experiments with soleus muscles from each of five individual rats.

\section{Labeling per nucleus}

Numerous factors might contribute to the accumulation of $\mathrm{Na}_{\mathrm{V}} 1.4$ mRNA at the NMJ. One of these is the well known clustering of myonuclei in the subsynaptic myoplasm (Tello, 1907, 1917; Ramon y Cajal, 1960; Kelly and Zacks, 1969; Couteaux, 1973), which might give rise to a local increase in the concentration of mRNA near the NMJ even if the amount of mRNA per nucleus was the same as elsewhere in the muscle fiber. To assess the importance of this factor, we estimated the relative amounts of $\mathrm{Na}_{\mathrm{V}} 1.4$ mRNA per nucleus at the $\mathrm{NMJ}$ and in $\mathrm{XJ}$ regions.

We determined the number of myonuclei in sections of muscle fibers, both those containing NMJs and those in XJ regions. The 

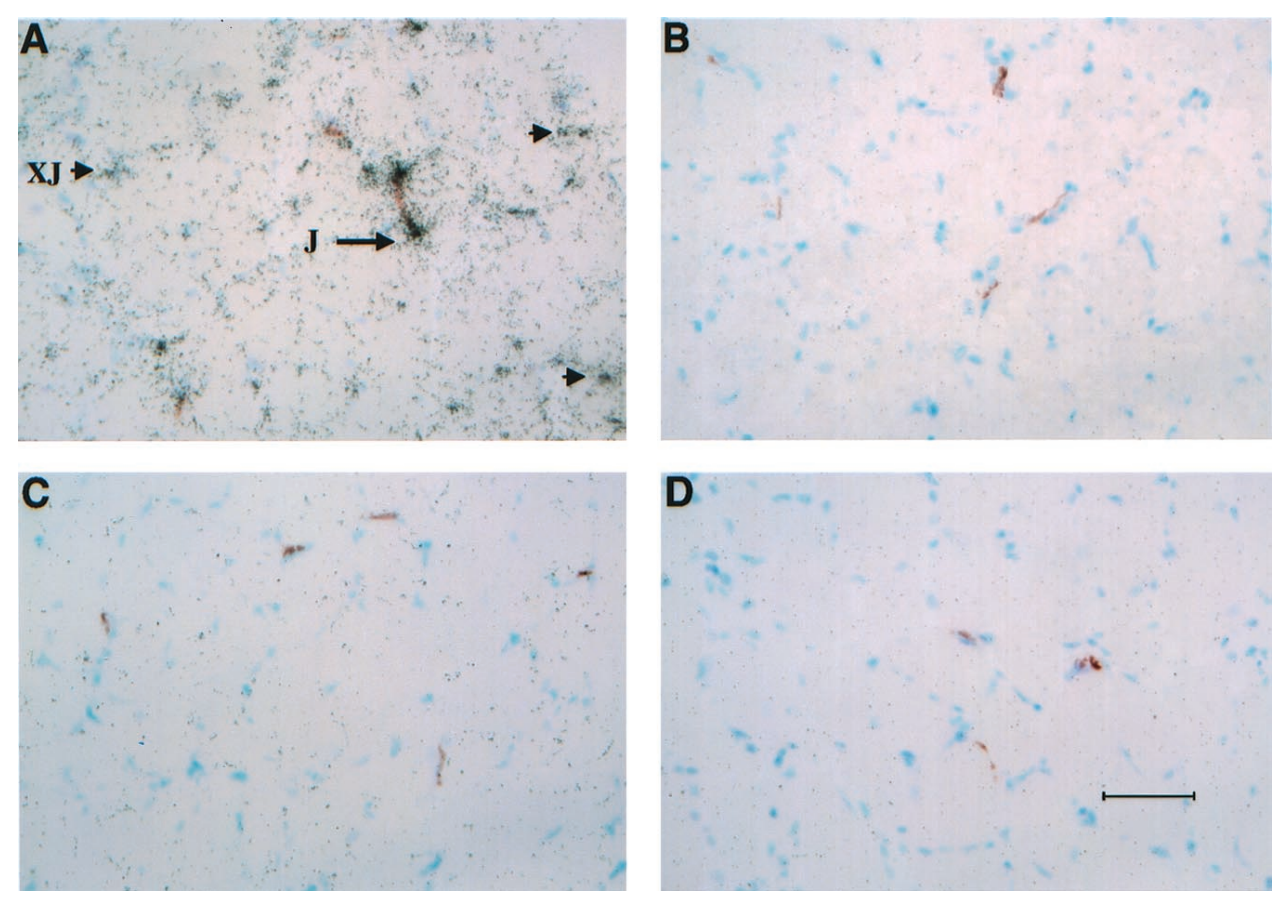

Figure 2. $\mathrm{Na}_{\mathrm{V}} 1.4$, but not $\mathrm{Na}_{\mathrm{V}} 1.5$, mRNA is concentrated at the $\mathrm{NMJ}$ in normal rat soleus muscle. $\mathrm{Na}_{\mathrm{v}} 1.4$ mRNA visualized after in situ hybridization and autoradiography as silver grains $(A)$ is densely accumulated at the NMJ (arrow), identified by the reddish-brown cholinestrase reaction product. Accumulation of $\mathrm{Na}_{\mathrm{V}} 1.4$ mRNA is also visible in $\mathrm{XJ}$ regions (arrowheads) as occasional smaller clusters. No such accumulation is seen after hybridization with the $\mathrm{Na}_{\mathrm{V}} 1.5$-specific antisense $(C)$ or the sense transcripts of either $\mathrm{Na}_{\mathrm{V}} 1.4$ or $\mathrm{Na}_{\mathrm{V}} 1.5$ probes ( $B$ and $D$, respectively). Scale bar, $50 \mu \mathrm{m}$. average number of myonuclei per muscle fiber section did not differ between $\mathrm{J}$ and $\mathrm{XJ}$ regions $(3.25 \pm 0.07$ vs $3.16 \pm 0.09 ; 150$ $\mathrm{J}$ and $132 \mathrm{XJ}$ fiber cross sections were examined). However, the mean number of nuclei in quadrants of fiber sections containing NMJs (Materials and Methods) was approximately twice the average value for quadrants in XJ regions $(1.59 \pm 0.04$ vs $0.83 \pm$ $0.09 ; 150 \mathrm{NMJ}$ and $132 \mathrm{XJ}$ fiber cross sections were examined). The clusters of grains from mRNA labeling at the NMJ were approximately the same size as the individual quadrants used to analyze nuclear distribution. To estimate the intensity of labeling per nucleus at the NMJ, we divided the total signal intensity in the area of a circle of $12 \mu \mathrm{m}$ radius centered on the grain clusters $\left(99.6 \mathrm{gl} / \mathrm{sec} / \mu \mathrm{m}^{2} \times 453 \mu \mathrm{m}^{2}\right)$ by the mean number of myonuclei in the quadrants containing NMJs (1.59) and compared that with the total signal intensity of XJ fiber cross sections $(5.14 \pm 2130$ $\mu \mathrm{m}^{2}$ ) divided by mean number of nuclei within them (3.16). This was more than eight times greater at the NMJ than away from it (28,363 vs $3402 \mathrm{gl} / \mathrm{sec} /$ nucleus).

\section{Denervation increases the levels of $\mathrm{Na}_{\mathrm{v}} 1.5 \mathrm{mRNA}$}

Denervation resulted in a dramatic increase in labeling of mRNA encoding $\mathrm{Na}_{\mathrm{V}} 1.5$, both at the $\mathrm{NMJ}$ and in $\mathrm{XJ}$ regions (Fig. $3 C$ ). This increase was detectable by the second day after denervation and reached a peak at 3-5 d, which was then sustained for at least 4 weeks (Fig. $3 E$ ). At all times, the intensity of labeling was much greater at the NMJs than in the $\mathrm{XJ}$ region. One week after denervation, intense clusters of silver grains were present at $\sim 85 \%$ of NMJs examined (34 of 40), and the intensity of labeling at these clusters NMJs was approximately nine times greater than the mean intensity in XJ regions $(90.4 \pm 2.46$ vs $10.3 \pm 0.82$ $\mathrm{gl} / \mathrm{sec}$; similar results obtained from four rats).

Denervation resulted in no significant change in the number or distribution of myonuclei, at or away from the NMJ $(3.03 \pm 0.09$ per cross section of denervated fibers; $1.66 \pm 0.04$ in quadrants containing NMJs compared with $0.75 \pm 0.05$ in XJ quadrants). Accordingly, the mean labeling intensity per nucleus at the NMJ was nearly fourfold greater than in XJ regions (24,646 vs 6288 $\mathrm{gl} / \mathrm{sec} /$ nucleus).
Occasional weaker clusters of $\mathrm{Na}_{\mathrm{V}} 1.5$ mRNA labeling were present in XJ regions. Approximately $30 \%$ of muscle fiber sections in the $\mathrm{XJ}$ region contained obvious grain clusters at times $>4$ d after denervation ( 55 of 150). Because each section contains approximately three myonuclei, this indicates that not $>10 \%$ of myonuclei in $\mathrm{XJ}$ regions are associated with grain clusters. The mean intensity of labeling at these XJ clusters was $52.0 \pm 1.9$ $\mathrm{gl} / \mathrm{sec} / \mu \mathrm{m}^{2}$, approximately half of that at NMJs. The intensity and pattern of labeling with the $\mathrm{Na}_{\mathrm{V}} 1.4$ probe (Fig. $3 D$ ) was similar to that in innervated controls (Fig. $3 B$ ).

In summary, denervation results in a substantial increase in the concentration of $\mathrm{Na}_{\mathrm{V}} 1.5$ mRNA, particularly near the NMJs, but has no effect on the level of $\mathrm{Na}_{\mathrm{V}} 1.4$ mRNA.

\section{Electrical stimulation downregulates $\mathrm{Na}_{\mathrm{v}} 1.5$ but not $\mathrm{Na}_{\mathbf{v}} 1.4$ mRNA}

To test the hypothesis that the increase in the amount of $\mathrm{Na}_{\mathrm{V}} 1.5$ mRNA after denervation is a result of the absence of electrical activity, we stimulated some of the denervated muscles in vivo with implanted electrodes (Windisch et al., 1998). These muscles were denervated for $5 \mathrm{~d}$, long enough to induce maximal $\mathrm{Na}_{\mathrm{V}} 1.5$ expression (Fig. 3E). They were then stimulated for 1 week, using a pattern of stimulation that is highly effective in preventing or reversing the accumulation of AChRs and their mRNA in XJ regions and preventing the loss of AChRs at the NMJs (Witzemann et al., 1991; Andreose et al., 1995).

Stimulation abolished the increase in $\mathrm{Na}_{\mathrm{V}} 1.5 \mathrm{mRNA}$, both at NMJs and in XJ regions (Fig. $4 A, C$; results reproducible from three individual rats). The level of labeling of these sections was similar to that of control innervated fibers (Fig. 2C). The levels at the NMJ of $\mathrm{Na}_{\mathrm{V}} 1.4$ mRNA were not affected by either denervation or stimulation of adult muscle fibers (Fig. 4B,D).

In Figure 5, we compare the levels of $\mathrm{Na}_{\mathrm{V}} 1.4$ and $\mathrm{Na}_{\mathrm{V}} 1.5$ mRNA per nucleus at NMJs and in XJ regions of control, denervated, and denervated-stimulated muscles. This comparison makes clear that the level of $\mathrm{Na}_{\mathrm{V}} 1.5$ mRNA is strongly suppressed by muscle activity, both in the muscle fiber generally and at the 

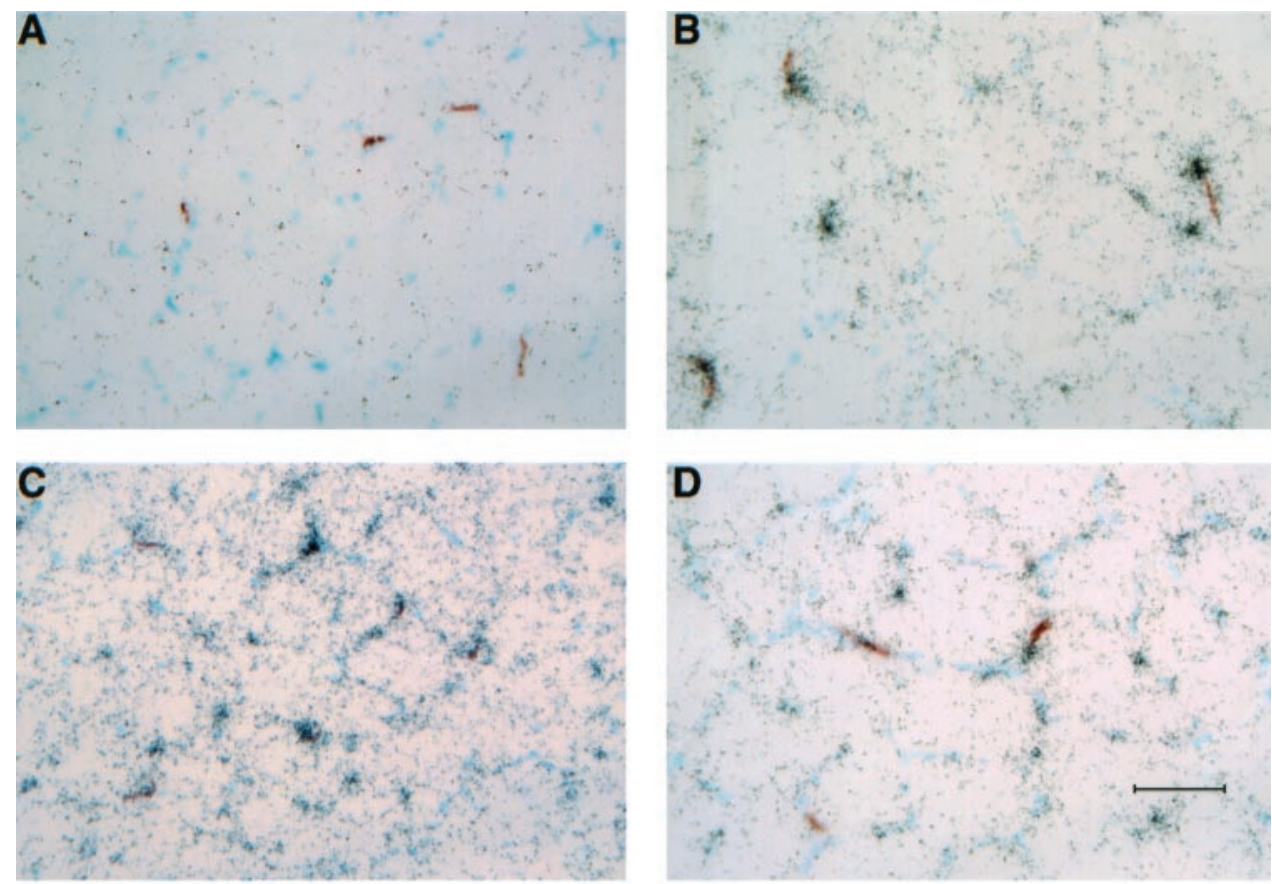

Figure 3. $\mathrm{Na}_{\mathrm{v}} 1.5 \mathrm{mRNA}$ is increased after denervation of adult muscle. Accumulation of silver grains is visible at the NMJ and in XJ regions after ISH with $\mathrm{Na}_{\mathrm{V}} 1.5$ antisense transcript in $7 \mathrm{~d}$ denervated soleus $(C)$ but not in control muscle $(A)$. $\mathrm{Na}_{\mathrm{v}} 1.4 \mathrm{mRNA}$ is concentrated at the majority of NMJs and $\mathrm{XJ}$ regions in both control $(B)$ and denervated $(D)$ rat soleus. Scale bar, $50 \mu \mathrm{m}$. Time course of $\mathrm{Na}_{\mathrm{v}} 1.5$ mRNA accumulation after denervation of adult rat muscle $(E)$. Mean intensity of labeling within a circle of $12 \mu \mathrm{m}$ radius centered on $\mathrm{J}$ clusters starts to increase by the second day, reaching a peak at the third day and is sustained for up to 4 weeks after denervation of adult soleus muscles $(\bullet)$. The same temporal pattern is seen for fiber cross sections $(\boldsymbol{\Delta})$ and clusters $(\mathbf{\square})$ in XJ regions $(40-50 \mathrm{~J}$ and 30-40 XJ clusters and $45 \mathrm{XJ}$ fibers were analyzed for each time point).

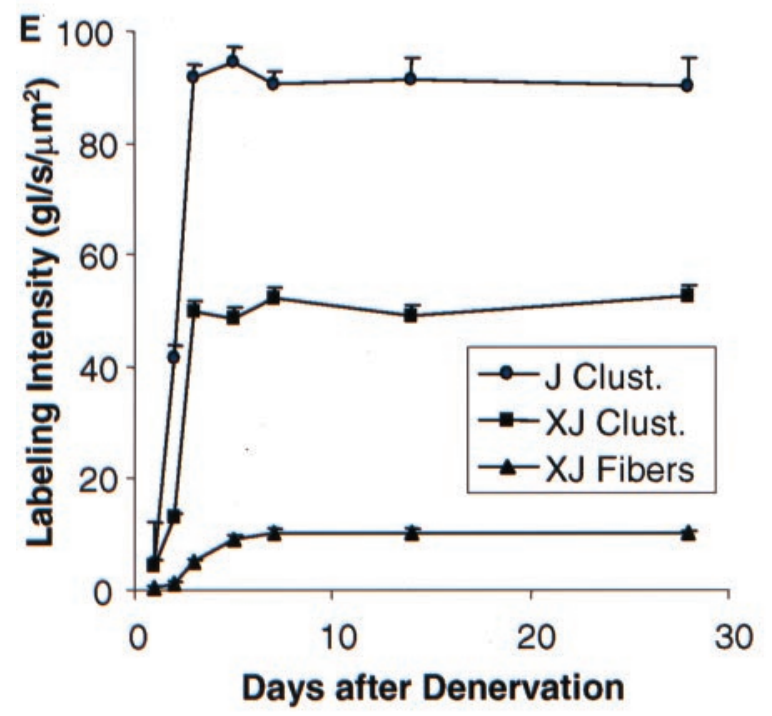

NMJ, although activity has no detectable effect on the levels of $\mathrm{Na}_{\mathrm{V}} 1.4$ mRNA.

\section{DISCUSSION}

In this study, we have taken advantage of the spatial resolution of in situ hybridization to show for the first time that mRNA encoding muscle-specific forms of $\mathrm{Na}_{\mathrm{V}} 1$ channels is concentrated at the NMJ. The hybridization signal from $\mathrm{Na}_{\mathrm{V}} 1.4$ mRNA is $\sim 20$ times stronger at normal NMJs than away from them. This implies a local increase in synthesis of $\mathrm{Na}_{\mathrm{V}} 1.4$ channels at the NMJ that is likely to contribute to the high density of these channels in the postsynaptic membrane (Lupa et al., 1993, 1995) and thus to the reliability of neuromuscular transmission (Wood and Slater, 2001).

The persistence of $\mathrm{Na}_{\mathrm{V}} 1.4$ mRNA away from the NMJ in normally active muscle fibers is consistent with an essential role of $\mathrm{Na}_{\mathrm{V}} 1.4$ channels in action potential propagation and distinguishes the regulation of $\mathrm{Na}_{\mathrm{V}} 1.4$ mRNA from that of most other mRNA species that are concentrated at the NMJ. In contrast,
$\mathrm{Na}_{\mathrm{V}} 1.5$ mRNA was not detectable in normal muscle. However, after denervation, it increased throughout the muscle and particularly at the NMJ. This increase was completely abolished by electrical stimulation. Thus, unlike a number of other "postsynaptic" mRNA species (see below), the accumulation of $\mathrm{Na}_{\mathrm{V}} 1.5$ mRNA at the NMJ is completely suppressed by muscle activity.

A number of features of the distribution of $\mathrm{Na}_{\mathrm{V}} 1$ mRNAs closely parallel the distribution of the proteins they encode. In normal adult muscle, $\mathrm{Na}_{\mathrm{V}} 1.4$ is the dominant $\mathrm{Na}_{\mathrm{V}} 1$ species present and is highly concentrated at the NMJ (Caldwell and Milton, 1988; Lupa et al., 1993). $\mathrm{Na}_{\mathrm{V}} 1.5$ is upregulated by denervation and inactivity (Harris and Thesleff, 1971; Caldwell and Milton, 1988; Kallen et al., 1990; Lupa et al., 1995; Pasino et al., 1996) and, when upregulated, is concentrated at NMJ (Caldwell and Milton, 1988, Lupa et al., 1995). Furthermore, the time course of the denervation-induced upregulation of $\mathrm{Na}_{\mathrm{V}} 1.5$ protein (Grampp et al., 1972) is similar to that of the mRNA 

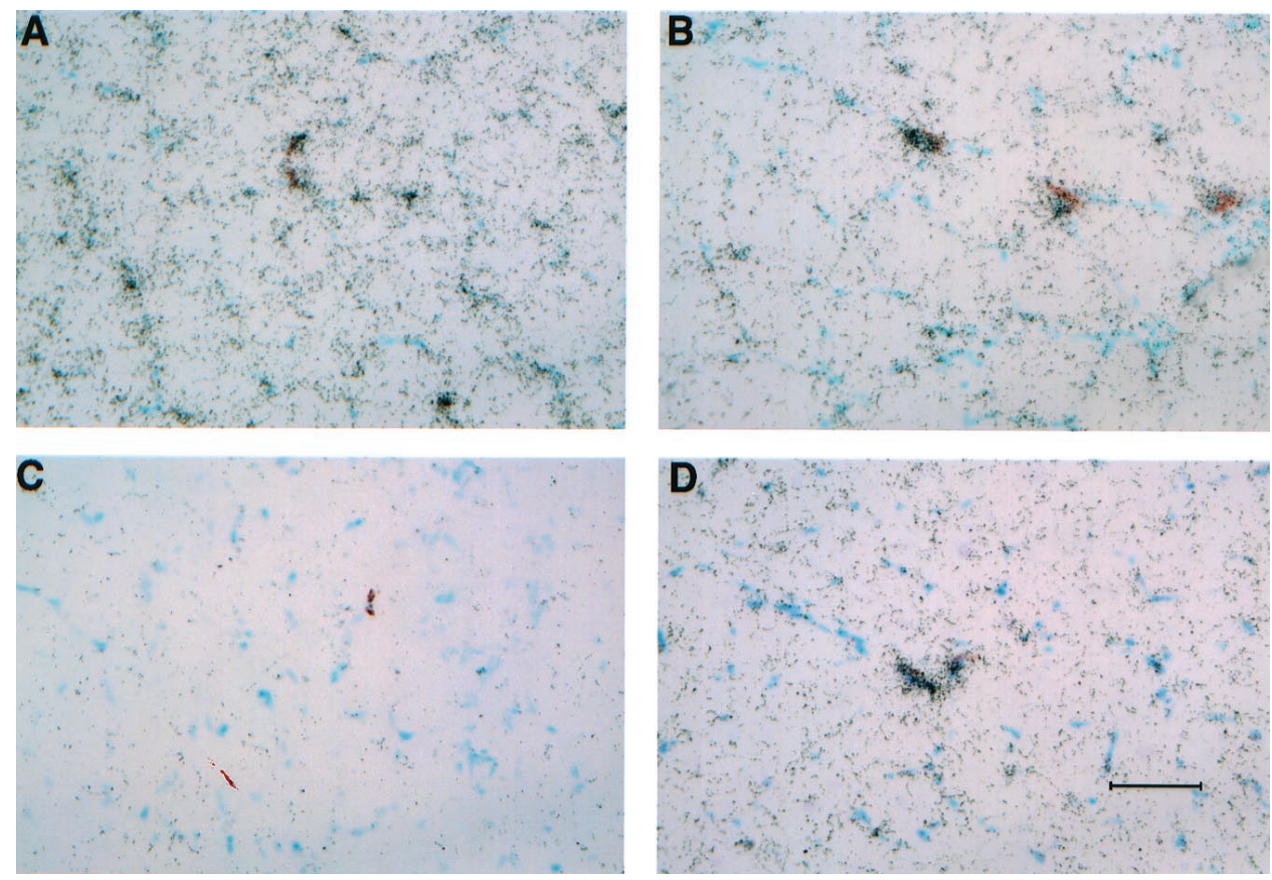

Figure 4. Electrical stimulation reverses $\mathrm{Na}_{\mathrm{V}} 1.5$ mRNA accumulation in denervated adult muscle. $\mathrm{Na}_{\mathrm{V}} 1.5 \mathrm{mRNA}$ clustering at the $\mathrm{NMJ}$ and $\mathrm{XJ}$ regions in $7 \mathrm{~d}$ denervated soleus $(A)$ is abolished by chronic electrical stimulation in vivo $(C)$ for 1 week as outlined in Materials and Methods. $\mathrm{Na}_{\mathrm{V}} 1.4$ mRNA is accumulated at the NMJ and XJ regions in both denervated $(B)$ and stimulated $(D)$ soleus muscle. Scale bar, $50 \mu \mathrm{m}$. reported here. Thus, our data suggest that regulation of the local levels of mRNA species plays an important part in determining physiologically relevant aspects of the distribution of $\mathrm{Na}_{\mathrm{V}} 1$ proteins.

\section{The patterns of $\mathrm{Na}_{\mathrm{v}} 1 \mathrm{mRNA}$ expression differ from those for other postsynaptic mRNAs}

Our observations suggest that the distribution and abundance of $\mathrm{Na}_{\mathrm{V}} 1$ mRNAs, like those encoding other postsynaptic proteins, are influenced by a balance between the effects of activity, which acts throughout the muscle fiber, and local nerve-derived factors, which are concentrated the NMJ (Fischbach and Rosen, 1997; Burden, 1998; Sanes and Lichtman, 1999). However, the patterns of expression of $\mathrm{Na}_{\mathrm{V}} 1$ mRNAs differ in important ways from those reported for other postsynaptic mRNAs.

$\mathrm{Na}_{\mathrm{V}} 1.4$ mRNA is highly concentrated at the NMJ but is also present away from it. Changes in activity have little effect on its abundance in either region. mRNAs for several AChR subunits are concentrated at the NMJ (Merlie and Sanes, 1985; Fontaine et al., 1988; Goldman and Staple, 1989; Brenner et al., 1990; Klarsfeld et al., 1991; Sanes et al., 1991; Simon et al., 1992), but their presence away from the NMJ is suppressed by activity (Goldman et al., 1988, Neville et al., 1991). This has led to models of AChR regulation in which muscle activity normally suppresses the expression of mRNAs away from NMJ, but a "dominant" effect of the nerve overcomes that suppression to enable a high concentration of AChR mRNA and protein to persist at the NMJ. $\mathrm{Na}_{\mathrm{V}} 1.4$ differs from those AChR subunits and from musclespecific receptor tyrosine kinase, N-CAM, and AChE (Covault and Sanes, 1985; Bowen et al., 1998; Jasmin et al., 1998), in that the abundance of its mRNA away from the NMJ is not markedly influenced by activity. Lack of sensitivity to activity is also a feature of $\epsilon$-subunit of AchR; however, its gene expression is restricted to the NMJ.

In contrast, activity suppresses the abundance of $\mathrm{Na}_{\mathrm{V}} 1.5$ mRNA both at the NMJ and away from it. This distinguishes it from most postsynaptic mRNA species, which remain concentrated at the NMJ in active muscle fibers. For $\mathrm{Na}_{\mathrm{V}} 1.5$, the down- regulating effects of activity dominate the upregulating effects of the nerve at the NMJ. The details of activity-dependent regulation of expression are not fully understood for any gene (Buonanno et al., 1998; Buonanno and Fields, 1999). E box motifs that bind myogenic factors of the myoD family confer activitydependent expression on AChR $\alpha$-, $\delta$-, and $\gamma$-subunits (Bessereau et al., 1994; Tang et al., 1994; Gilmour et al., 1995; Walke et al., 1996). Whereas $\mathrm{E}$ box motifs have been identified in the $5^{\prime}$ flanking region of both $\mathrm{Na}_{\mathrm{V}} 1.4$ (Kraner et al., 1998) and $\mathrm{Na}_{\mathrm{V}} 1.5$ genes (Sheng et al., 1994), no direct link of these sequences to activity-dependent expression of the $\mathrm{Na}_{\mathrm{V}} 1.5$ gene has been demonstrated.

The mRNA species encoding $\gamma$-AChR is also downregulated by activity, both at and away from NMJs. After denervation, its mRNA initially increases in abundance to an approximately similar extent all along the muscle fiber. After 5-7 d, the region of high mRNA abundance becomes limited to the NMJ, but this seems to be a result of a decrease in abundance in the perijunctional region rather than an increase at the NMJ (Kues et al., 1995). In contrast, $\mathrm{Na}_{\mathrm{V}} 1.5 \mathrm{mRNA}$ is highly concentrated at the NMJ within 2-3 d of denervation, and that situation is maintained with little change for up to 4 weeks. This suggests that different mechanisms may control the accumulation of these two mRNA species.

\section{What controls increased concentration of $\mathrm{Na}_{\mathrm{v}} 1$ mRNAs at the NMJ?}

It is clear that, for $\mathrm{Na}_{\mathrm{V}} 1.4$ and 1.5 , the increased concentration of mRNA is not simply a result of nuclear accumulation. It is generally believed that increased mRNA concentration results from action of nerve-derived signaling molecules on gene transcription in postsynaptic myonuclei. Although other mechanisms are possible, including regulation of mRNA stability and directed translocation of mRNA species to the postsynaptic region, there is little evidence concerning their possible involvement at the NMJ.

The best candidate for a mediator of nerve-derived transcriptional regulation of AChR subunits is neuregulin (Fischbach and 

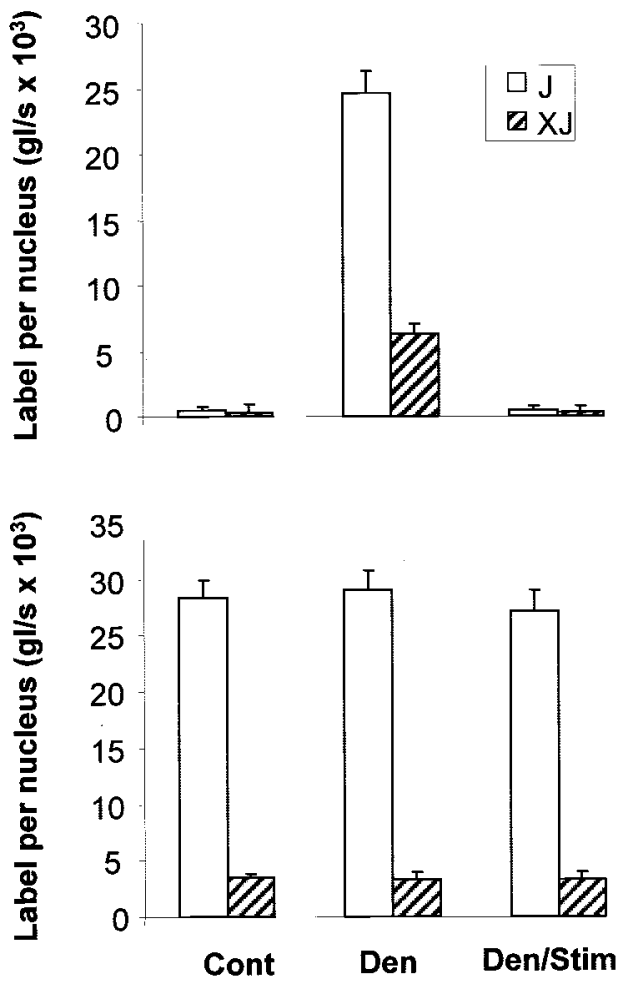

Figure 5. $\mathrm{Na}_{\mathrm{v}} 1.5$ mRNA accumulation in adult muscle is controlled by activity. Intensity of $\mathrm{Na}_{\mathrm{V}} 1.5$ labeling per nucleus is nearly fourfold greater at $\mathrm{J}$ than $\mathrm{XJ}$ nuclei (top panel) in denervated muscle, which is reduced to control levels after electrical stimulation $(p<0.001)$. Labeling intensity with $\mathrm{Na}_{\mathrm{V}} 1.4$ probe at $\mathrm{J}$ and $\mathrm{XJ}$ nuclei is not affected by either denervation or stimulation of adult soleus muscle (bottom panel). Thirty to $40 \mathrm{~J}$ clusters and $\mathrm{XJ}$ fibers were analyzed for each category.

Rosen, 1997; Burden, 1998; Sanes and Lichtman, 1999). Neuregulin has also been shown to increase the amount of $\mathrm{Na}_{\mathrm{V}} 1.4$ in muscle cells (Corfas and Fischbach, 1993), but its effects on mRNA have not been investigated. A class of regulatory sequences that mediate the effects of neuregulin on the abundance of AChR mRNA species at the NMJ has been identified (Chu et al., 1995; Jo et al., 1995; Si et al., 1997). A 6 bp "N box" within the neuregulin response sequence can direct synapse-specific expression of a number of proteins (Koike et al., 1995; Duclert et al., 1996; Gramolini et al., 1999). Response to neuregulin involves binding of Ets family transcription factors to $\mathrm{N}$ box sequences (Fromm and Burden, 1998; Sapru et al., 1998; Schaeffer et al., 1998; Gramolini et al., 1999). We searched the published 5' flanking region sequences of the $\mathrm{Na}_{\mathrm{V}} 1.4$ gene (Kraner et al., 1998; GenBank accession number AF042092) and found no $\mathrm{N}$ boxes. However, we identified an N box (TTCCGG) within the first intron of the genomic sequence of $\mathrm{Na}_{\mathrm{V}} 1.5$ (Sheng et al., 1994; GenBank accession number L11243). It is possible that this sequence could influence the accumulation of $\mathrm{Na}_{\mathrm{V}} 1.5$ mRNA at the NMJ after denervation.

\section{$\mathrm{Na}_{\mathbf{v}} \mathbf{1}$ mRNA distribution in extrajunctional regions}

The use of in situ hybridization has revealed previously undetected details of local variations in $\mathrm{Na}_{\mathrm{V}} 1$ mRNA abundance in XJ regions. Clusters of $\mathrm{Na}_{\mathrm{V}} 1 \mathrm{mRNAs}$ are present in approximately one-third of muscle fiber sections, corresponding to approximately one cluster for every 10 myonuclei. A qualitatively similar pattern has been reported for the $\mathrm{AChR} \alpha$-subunit in chick muscle cells (Fontaine et al., 1988; Bursztajn et al., 1989) and for utrophin (Vater et al., 1998).

One possible explanation for this clustering of mRNA is that individual myonuclei alternate between periods of transcriptional activity and inactivity, as has been proposed for other genes in muscle (Newlands et al., 1998). In the case of $\mathrm{Na}_{\mathrm{V}} 1$ mRNAs, the intensity of the XJ clusters is approximately one-third to one-half of that of the clusters present at the NMJ. Given the number of myonuclei at the NMJ, this suggests that the amount of mRNA near an "active" nucleus is similar in $\mathrm{J}$ and XJ regions. In the context of a model of "pulsatile" gene expression, this suggests that XJ myonuclei express $\mathrm{Na}_{\mathrm{V}} 1$ genes at a similar rate to those away from the NMJ but for a smaller fraction of the time.

\section{Interaction between nerve and activity}

In contrast to other proteins that are specifically concentrated in the postsynaptic region, $\mathrm{Na}_{\mathrm{V}} 1 \mathrm{~s}$ are also required throughout the muscle fiber surface. Our studies using in situ hybridization have revealed similarly distinctive patterns of $\mathrm{Na}_{\mathrm{V}} 1$ mRNA distribution. Whichever species of $\mathrm{Na}_{\mathrm{V}} 1 \mathrm{mRNA}$ is present, it is highly concentrated at the NMJ. However, $\mathrm{Na}_{\mathrm{V}} 1.4$ mRNA, unlike the mRNAs encoding most postsynaptic proteins, persists in significant concentration away from the NMJ in fully active muscles. On the other hand, $\mathrm{Na}_{\mathrm{V}} 1.5 \mathrm{mRNA}$, although highly concentrated at the NMJ when expressed, is downregulated by muscle activity. Thus, the factors that induce upregulation of $\mathrm{Na}_{\mathrm{V}} 1.5$ at the NMJ do not confer resistance to suppressive effects of muscle activity. In conclusion, although a local effect of nerve and a more "global" effect of muscle activity act to regulate the abundance and distribution of $\mathrm{Na}_{\mathrm{V}} 1$ mRNAs, the balance between those factors differs from that acting to control other postsynaptic proteins.

\section{REFERENCES}

Andreose JS, Fumagalli G, Lømo T (1995) Number of junctional receptors: control by neural and muscular influence in the rat. J Physiol (Lond) 483:397-406.

Bessereau J-L, Stratford-Perricaudet LD, Piette J, Poupon CL, Changeux J-P (1994) In vivo and in vitro analysis of electrical activity-dependent expression of muscle acetylcholine receptor genes using adenovirus. Proc Natl Acad Sci USA 91:1304-1308.

Boudier JL, Le Treut T, Jover E (1992) Autoradiographic localization of voltage-dependent sodium channels on the mouse neuromuscular junction using ${ }^{125} \mathrm{I}-\alpha$ scorpion toxin. II. Sodium channel distribution on postsynaptic membranes. J Neurosci 12:454-466.

Bowen DC, Park SJ, Bodine S, Stark JL, Valenzuela DM, Stitt TN, Yancopoulos GD, Lindsay RM, Glass DJ, DiStefano PS (1998) Localization and regulation of Musk at the neuromuscular junction. Dev Biol 199:309-319.

Buonanno A, Fields RD (1999) Gene regulation by patterned electrical activity during neural and skeletal muscle development. Curr Opin Neurobiol 9:110-120.

Buonanno A, Cheng J, Venepally P, Weis J, Calvo S (1998) Activitydependent regulation of muscle genes: repressive and stimulatory effect of innervation. Acta Physiol Scand 163:S17-S26.

Brenner HR, Witzemann V, Sakmann B (1990) Imprinting of acetylcholine receptor messenger RNA accumulation in mammalian neuromuscular synapses. Nature 344:544-547.

Burden SJ (1998) The formation of neuromuscular synapses. Genes Dev 12:133-148.

Bursztajn S, Berman SA, Gilbert W (1989) Differential expression of acetylcholine receptor mRNA in nuclei of cultured muscle cells. Proc Natl Acad Sci USA 86:2923-2932.

Caldwell JH, Milton RL (1988) Sodium channel distribution in normal and denervated rodent and snake skeletal muscle. J Physiol (Lond) 401:145-161.

Catterall WA (1992) Cellular and molecular biology of voltage-gated sodium channels. Physiol Rev 72 [Suppl 4]:S15-S48.

Chu GC, Moscoso LM, Sliwkowski MX, Merlie JP (1995) Regualtion of acetylcholine receptor epsilon subunit gene by recombinant ARIA: an in vitro model for transynaptic gene regulation. Neuron 14:329-339.

Corfas G, Fischbach GD (1993) The number of Na channels in cultured chick muscle is increased by ARIA, an acetylcholine receptor-inducing activity. J Neurosci 13:2118-2125. 
Couteaux R (1973) Motor end plate structure. In: Structure and function of muscle (Bourne GH, ed), pp 483-530. New York: Academic.

Covault J, Sanes JR (1985) Neural cell adhesion molecule (N-CAM) accumulates in denervated and paralyzed skeletal muscle. Proc Natl Acad Sci USA 82:4544-4548.

Duclert A, Savatier N, Schaeffer L, Changeux J-P (1996) Identification of an element crucial for the subsynaptic expression of acetylcholine receptor $\epsilon$-subunit gene. J Biol Chem 271:17433-17438.

Fischbach GD, Rosen K (1997) ARIA: a neuromuscular junction neuregulin. Annu Rev Neurosci 20:429-458.

Flucher BE, Daniels MP (1989) Distribution of $\mathrm{Na}^{+}$channels and ankyrin in neuromuscular junctions is complementary to that of acetylcholine receptors and the $43 \mathrm{kd}$ protein. Neuron 3:163-175.

Fontaine B, Sassoon D, Buckingham M, Changeux J-P (1988) Detection of nicotinic acetylcholine receptor $\alpha$-subunit mRNA by in situ hybridization at neuromuscular junctions of 15-day-old chick striated muscles. EMBO J 7:603-609.

Fromm L, Burden SJ (1998) Synapse-specific and neuregulin-induced transcription require an Ets site that binds $\mathrm{GABP} \alpha / \mathrm{GABP} \beta$. Genes Dev 12:3074-3083.

Gilmour BP, Goldman D, Chahine KG, Gardner PD (1995) Electrical activity suppresses nicotinic acetylcholine receptor gamma subunit promoter activity. Dev Biol 168:416-428.

Goldman D, Staple J (1989) Spatial and temporal expression of acetylcholine receptor RNAs in innervated and denervated rat soleus muscle. Neuron 3:219-228.

Goldman D, Brenner HR, Heinemann S (1988) Acetylcholine receptor $\alpha-, \beta-, \gamma-$, and $\delta$-subunit mRNA levels are regulated by muscle activity. Neuron 1:329-333.

Gramolini AO, Agnus LM, Schaeffer L, Burton EA, Tinsley JM, Davies KE, Changeux J-P, Jasmin BJ (1999) Induction of utrophin gene expression by heregulin in skeletal muscle cells: role of N-box motif and GA binding protein. Proc Natl Acad Sci USA 96:3223-3227.

Grampp W, Harris JB, Thesleff S (1972) Inhibition of denervation changes in skeletal muscle by blockers of protein synthesis. J Physiol (Lond) 221:734-754.

Hall WZ, Sanes JR (1993) Synaptic structure and development: the neuromuscular junction. Neuron [Suppl] 10:99-121.

Harris JB, Thesleff S (1971) Studies on tetrodotoxin resistant action potentials in denervated skeletal muscle. Acta Physiol Scand 83:383-388.

Jasmin BJ, Boudreau-Lariviere C, Adatia FA, Angus L, Chan RYY, Kotlarewski M, Krupa AM, Mankal FA (1998) Molecular mechanisms controlling the synapse-specific expression and activity-linked regulation of acetylcholinesterase in skeletal muscle fibers. In: Structure and function of cholinestrases and related proteins (Doctor BP, ed), pp 45-50. New York: Plenum.

Jo SA, Zhu X, Marchionni MA, Burden SJ (1995) Neuregulins are concentrated at nerve-muscle synapses and activate ACh-receptor gene expression. Nature 373:158-161.

Kallen RG, Sheng Z-H, Yang J, Chen L, Rogart RB, Barchi RL (1990) Primary structure and expression of a sodium channel characteristic of denervated and immature rat skeletal muscle. Neuron 4:233-242.

Kelly AM, Zacks SI (1969) The fine structure of motor end-plate myogenesis. J Cell Biol 42:154-169.

Klarsfeld A, Bessereau J-L, Salmon A-M, Triller A, Babinet C, Changeux J-P (1991) An acetylcholine receptor $\alpha$-subunit promoter conferring preferential synaptic expression in muscle of transgenic mice. EMBO J 10:625-632.

Koike S, Schaeffer L, Changeux J-P (1995) Identification of a DNA element determining synaptic expression of the mouse acetylcholine receptor $\alpha$-subunit gene. Proc Natl Acad Sci USA 92:10624-10628.

Kraner SD, Rich MM, Kallen RG, Barchi RL (1998) Two E-boxes are the focal point of muscle-specific skeletal muscle type $1 \mathrm{Na}^{+}$channel gene expression. J Biol Chem 273:11327-11334.

Kues WA, Brenner HR, Sakmann B, Witzemann V (1995) Local neurotrophic repression of gene transcripts encoding fetal AchRs ar rat neuromuscular synapses. J Cell Biol 130:949-957.

Lupa MT, Krzemien DM, Schaller KL, Caldwell JH (1993) Aggregation of sodium channels during development and maturation of the neuromuscular junction. J Neurosci 13:1326-1336.

Lupa MT, Krzemien DM, Schaller KL, Caldwell JH (1995) Expression and distribution of sodium channels in short- and long-term denervated rodent skeletal muscle. J Physiol (Lond) 481:109-118.

Martin AR (1994) Amplification of neuromuscular transmission by postjunctional folds. Proc R Soc Lond B Biol Sci 258:321-326.

Merlie JP, Sanes JR (1985) Concentration of acetylcholine receptor mRNA in synaptic regions of adult muscle fibers. Nature 317:66-68.

Neville C, Schmidt M, Schmidt J (1991) Kinetics of expression of ACh receptor alpha-subunit mRNA in denervated and stimulated muscle. NeuroReport 2:655-657.
Newlands S, Levitt LK, Robinson CS, Karpf ABC, Hodgson VRM, Wade RP, Hardeman EC (1998) Transcription occurs in pulses in muscle fibers. Genes Dev 12:2748-2758.

Pasino E, Buffelli M, Arancio O, Busetto G, Salviati A, Cangiano A (1996) Effects of long-term conduction block on membrane properties of reinnervated and normally innervated rat skeletal muscle. J Physiol (Lond) 497:457-472.

Ramon y Cajal SY (1960) Remarks on the motor plaques of the mammalian tongue. In: Studies on vertebrate neurogenesis (Goth L, translator), pp 206-214. Springfield, IL: Thomas.

Rogart RB, Cribbs LL, Muglia LK, Kephart DD, Kaiser MW (1989) Molecular cloning of a putative tetrodotoxin-resistant rat heart $\mathrm{Na}^{+}$ channel isoform. Proc Natl Acad Sci USA 86:8170-8174.

Sanes JR, Lichtman J (1999) Development of the vertebrate neuromuscular junction. Annu Rev Neurosci 22:389-442.

Sanes JR, Johnson YR, Kotzbauer PT, Mudd J, Hanley Th, Martinou JC, Merlie JP (1991) Selective expression of an acetylcholine receptorlacZ transgene in synaptic nuclei of adult muscle fibers. Development 113:1181-1191.

Sapru MK, Florance SK, Kirk C, Goldman D (1998) Identification of a neuregulin and protein-tyrosine phosphatase response element in the nicotinic acetylcholine receptor e subunit gene: regulatory role of an Ets transcription factor. Proc Natl Acad Sci USA 95:1285-1294.

Schaeffer L, Duclert N, Huchet-Dymanus M, Changeux J-P (1998) Implication of multisubunit Ets-related transcription factor in synaptic expression of the nicotinic acetylcholine receptor. EMBO J 17:3078-3090.

Sheng Z-H, Zhang H, Barchi RL, Kallen RG (1994) Molecular cloning and functional analysis of the promoter of rat skeletal muscle voltagesensitive sodium channel subtype 2 (rSkM2): evidence for musclespecific nuclear protein binding to the core promoter. DNA Cell Biol 13:9-23.

Si J, Miller DS, Mei L (1997) Identification of an element required for acetylcholine receptor-inducing activity (ARIA)-induced expression of the acetylcholine receptor e subunit gene. J Biol Chem 272:10367-10371.

Simon AM, Hoppe P, Burden SJ (1992) Spatial restriction of AChR gene expression to subsynaptic nuclei. Development 114:545-553.

Tang J, Jo SA, Burden SJ (1994) separate pathways for synaps-specific and electrical activity-dependent gene expression in skeletal muscle. Development 120:1799-1804.

Tello JF (1907) Dégénération et régénération des plaques motrices après la section des nerfs. Trab Lab Invest Biol Univ Madr 5:117-149.

Tello JF (1917) Génesis de la terminaciones nerviosas motrics y sensitivas. I. En el sistema locomotor de los vertebrados superiosres. Histogénesis muscular. Trab Lab Invest Biol Univ Madr 15:101-199.

Trimmer JS, Cooperman SS, Tomiko SA, Z hou J, Crean SM, Boyle MB, Kallen RG, Sheng Z, Barchi RL, Sigworth FJ, Goodman RH, Agnew WS, Mandel G (1989) Primary structure and functional expression of mammalian skeletal muscle sodium channel. Neuron 3:33-49.

Vater R, Young C, Anderson LVB, Lindsay S, Blake DJ, Davies KE, Zuelling R, Slater CR (1998) Utrophin mRNA expression in muscle is not restricted to the neuromuscular junction. Mol Cell Neurosci 10:229-242.

Walke W, Xiao G, Goldman D (1996) Identification and characterization of a 47 base pair activity-dependent enhancer of the rat nicotinic acetylcholine receptor d-subunit promoter. J Neurosci 16:3641-3651.

Windisch A, Gunderson K, Szabolcs MJ, Gruber H, Lømo T (1998) Fast to slow transformation of denervated and electrically stimulated rat muscle. J Physiol (Lond) 510 2:623-632.

Witzemann V, Brenner HR, Sakmann B (1991) AChR subunit mRNA at rat neuromuscular synapse. J Cell Biol 114:125-141.

Wollner DA, Catterall WA (1986) Localization of sodium channels in axon hillocks and initial segments of retinal ganglion cells. Proc Natl Acad Sci USA 83:8424-8428.

Wood SJ, Slater CR (1997) The contribution of postsynaptic folds to the safety factor for neuromuscular transmission in rat fast- and slowtwitch muscles. J Physiol (Lond) 500:165-176.

Wood SJ, Slater CR (1998) $\beta$-spectrin is colocalized with both voltagegated sodium channels and ankyrin ${ }_{\mathrm{G}}$ at the adult rat neuromuscualr junction. J Cell Biol 140:675-684.

Wood SJ, Slater CR (2001) Safety factor at the neuromuscular junction. Prog Neurobiol 64:327-429.

Yang J, Sladky JT, Kallen RG, Barchi RL (1991) TTX-sensitive and TTX-insensitive sodium channel mRNA transcripts are independently regulated in adult skeletal muscle after denervation. Neuron 7:421-427.

Young C, Lindsay S, Vater R, Slater CR (1998) An improved method for the simultaneous demonstration of mRNA and estrase activity at the human neuromuscular junction. Histochem J 30:7-11.

Zhang M, McLennan IS (1994) Use of antibodies to identify satellite cells with a light microscope. Muscle Nerve 17:987-994. 